This item was submitted to Loughborough's Institutional Repository (https://dspace.lboro.ac.uk/) by the author and is made available under the following Creative Commons Licence conditions.

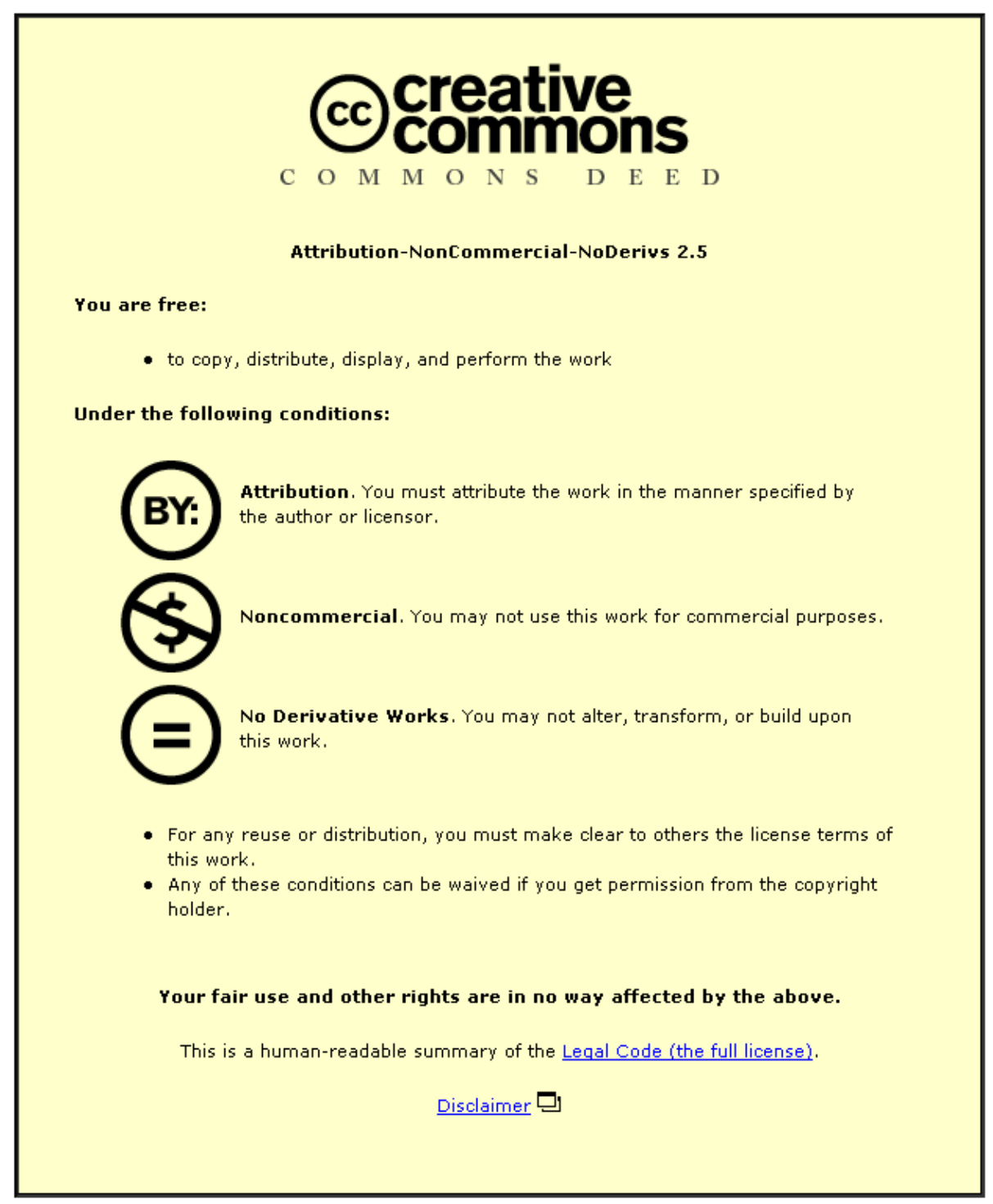

For the full text of this licence, please go to: http://creativecommons.org/licenses/by-nc-nd/2.5/ 


\title{
UK AIR TRAVEL PREFERENCES: EVIDENCE FROM AN EAST MIDLANDS HOUSEHOLD SURVEY
}

\author{
Tim Ryley ${ }^{*}$ and Lisa Davison \\ Transport Studies Group, Department of Civil and Building Engineering, \\ Loughborough University, Leicestershire, LE11 3TU. United Kingdom
}

\begin{abstract}
Air travel preferences of the general public are examined from a household survey in the Charnwood Borough Council area of Leicestershire, within the East Midlands region of the UK. Survey analysis shows that individuals frequently fly using low cost airlines for leisure purposes, and often travel long distances to access airports. The price sensitivity of respondents to changes in air fares varies across the sample. Most respondents agree that there are both economic benefits and environment disbenefits associated with aviation.
\end{abstract}

\section{Keywords}

Air, Travel, Survey, Demand, Segmentation, Environment

\section{Introduction}

Individuals are flying more than ever and over greater distances. Air travel has increased five-fold in the UK over the past 30 years, and demand is projected to be between two and three times current levels by 2030 (UK Department for Transport, 2003). Although this increasing demand has provided greater opportunities, there are environmental challenges to ensure that the development of aviation is more sustainable.

This paper considers increasing air travel demand amongst the general public; there is a pertinent research need to understand more fully the underlying travel motivations of increased air travel. Demand could change in response to specific events (e.g. the attacks of September 11, 2001), public opinion (e.g. more aware of negative environmental aspects of flying) and/or air fare changes (e.g. increases in oil prices). Travel motivations, particularly for leisure demand, could relate to aspects such as location of friends and relatives, social commitments, flexibility of travel, and preferences for a particular mode and/or carrier. In response to air fare changes, some individuals may be prepared to pay more to travel; other may decide against travelling, perhaps because they cannot afford to travel by air.

\footnotetext{
* Corresponding author: T.J.Ryley@lboro.ac.uk
} 
The demand for leisure travel has increased over the last ten or so years; trip-makers take holidays more frequently but for shorter periods (Mason, 2005).

Evidence from the UK shows that, as the low-cost carrier sector has grown, there has been a shift from domestic to international holiday-taking, and from buying a holiday package deal to independent booking (Graham, 2006).

The research case study is Charnwood Borough Council, one of seven Borough/District Councils in Leicestershire, United Kingdom. Charnwood Borough Council is located in the centre of a triangle comprising the three cities of Derby, Nottingham and Leicester; Loughborough is the largest town within the Council area.

The primary airport for Charnwood Borough Council residents is East Midlands airport (EMA), just outside and to the North-West of the Council area (known as Nottingham East Midlands airport until $6^{\text {th }}$ December 2006). EMA has grown dramatically in recent times. For instance, the number of passengers on EMA international scheduled flights increased from 0.2 million to 2 million between 1990 and 2004 (Civil Aviation Authority, 2005). District level analysis shows that 54\% of EMA passengers are from the East Midlands region (UK Department for Transport, 2002).

All three of the primary low cost airlines (bmi baby, easyJet and Ryanair) operate flights from EMA. EMA was the first base for the no-frills subsidiary bmi baby, established in 2002. In 2004, Ryanair announced it was transferring 70\% of its services from Birmingham International airport to East Midlands airport because, according to the airline, Birmingham required Ryanair to pay 100\% more in airport charges (from Ryanair press release, quoted in Civil Aviation Authority, 2005). Routes from EMA, operated by the three low cost airlines, as of August 2006 are shown in Table 1.

Ryanair has since expanded operations at EMA to 27 routes. From February 2007, Ryanair also flies to the following 10 destinations: Alghero (Sardinia), Bratislava (Slovakia), Granada (Spain), Inverness (Scotland), Knock (Ireland), Krakow (Poland), Bergamo Milan (Italy), Pisa (Italy), Santiago (Spain) and Valencia (Spain). It could be surmised that from EMA, Ryanair is expanding its European routes in all directions, whilst bmi baby tends to serve city-break destinations and easyJet has more 'sun-seeker' destinations. 


\section{Research design}

The primary aim of the Charnwood air travel household survey is to examine air travel preferences of the general public. Data collection was through postal questionnaires, a low cost method that does not involve high personnel travel costs. However, there can be difficulties with postal questionnaire surveys in obtaining a representative sample due to low response rates. There may also be potential bias in the responses received due to respondent fatigue if questionnaires are too long ${ }^{1}$.

A self-completion questionnaire was posted out to each household sampled, together with a pre-paid return envelope. The request was for one adult within the household to complete the questionnaire and return it in the envelope provided. The questionnaire contains a vast array of variables, relating to air travel experiences and possible future air travel choices, together with background socio-economic and transport information. The five sections within the questionnaire, together with the variables, are shown in Table 2.

The sampling strategy for the air travel survey was to select two sub-areas within the Charnwood Borough Council area, using a combination of clustered and random sampling. The rationale was to attain a sufficient sample for two distinct spatial population groups. The sampling frame was the edited version of the Electoral Register, a record of residents within the Council area eligible to vote ${ }^{2}$. One household was randomly selected from each of the two Electoral Register sections, one for the town of Loughborough and one for the rural surrounds. There were 1,000 households sampled in close proximity to each household; the two sub-areas cover central Loughborough and east Charnwood respectively.

\section{The sample}

Of the 2,000 questionnaires posted in October 2006, 361 were returned. This represents an overall response rate of $18 \%$, similar to other household surveys (e.g. Cooper et al, 2001). The returns from the sub-areas vary: $12 \%$ from central Loughborough, $24 \%$ from east Charnwood. The lower response rate from the central Loughborough sub-area may be due to lower income households (a factor affecting response rates in a previous survey conducted by one of the authors - Ryley, 2005), a possible language barrier (e.g. many individuals originate from Asia and may not have understood the questionnaire) and/or that the population within this sub-area are much younger (e.g. may have less time to complete questionnaires).

\footnotetext{
${ }^{1}$ The Charnwood air travel household survey questionnaire was seven A4 pages long, judged to be around the upper limit of an acceptable questionnaire length.

2 The edited version of the Electoral Register was obtained from Charnwood Borough Council. The edited Electoral Register does not include individuals who requested removal of their names from the version given to outside organisations (it is estimated that $60 \%$ of households are in the edited version).
} 
The sample contains $57 \%$ female and $43 \%$ male respondents; this proportion is the same across sub-areas. Of households in the sample, 32\% contain children, again similar across sub-areas. The sample from central Loughborough is much younger (62\% aged between 18 and 44). This is reflected in the current status, with many of the east Charnwood sample in retirement (26\%). Regular use (i.e. at least once a week) of a car or van at home is higher in the east Charnwood sample (97\%) than the central Loughborough sample (77\%).

The analysis of the Charnwood air travel survey focuses on three aspects: air travel experiences, attitudinal statements, and price sensitivity of respondents to changes in air fares.

\section{Air travel experiences}

Of the 361 respondents, 67 had not flown during the previous year. At the other extreme, 36 respondents had flown at least five times the previous year. When split into leisure and business trips, it is leisure trips that predominate: 287 had undertaken at least one leisure trip the previous year, 50 had undertaken at least one business trip. The 67 'non-flyers' are over-represented by those retired and living in central Loughborough; the opposite is the case for 'frequent flyers' (flown at least four times the previous year).

Of the nine airports listed, the most used airport was East Midlands Airport (EMA); $88 \%$ of respondents have flown from the airport at some point (53\% flew from EMA the previous year). However, almost as many respondents have used Birmingham International airport (79\%). The four London airports also have high usage rates amongst respondents (Heathrow 67\%, Gatwick 63\%, Luton 58\% and Stansted 44\%). This illustrates the willingness of individuals to travel long distances in order to access airports (all of the London airports are over 80 miles away from the two survey areas). Only the much smaller airports have low proportions: Coventry airport 13\%, Robin Hood airport (Doncaster Sheffield) 1\%.

For travel to EMA amongst respondents, the motor car predominates, either using their own vehicle, or receiving a lift from family or friends. Even so, $22 \%$ in central Loughborough take the public bus to access EMA. There is a regular airport shuttle bus (every 30 minutes between 5:20 and 18:50) from central Loughborough to EMA; the journey takes 25 minutes. A fifth of respondents (equally split across the two sub-areas) tend to take the taxi. Usage of EMA is higher amongst east Charnwood residents; 92\% of east Charnwood residents have used EMA compared with $79 \%$ of central Loughborough residents. 
Eight typical low cost airline destinations were examined in the survey (Edinburgh, Dublin, Prague, Rome, Berlin, Alicante, Malaga and Faro). All are offered by at least one of the primary low cost carriers from EMA (bmi baby, easyJet, Ryanair). Many respondents had visited these destinations from EMA. Aside from Berlin (only 2\% had visited Berlin from EMA), each destination had been visited by between $10 \%$ and $29 \%$ of respondents on flights from EMA. Malaga is the most frequently visited destination.

Respondents were asked to rank these eight destinations in the order they would like to visit. Of the destinations, Rome is by far the most popular (35\% of respondents), mainly because of the historical sights and culture. This is similar to the reasons for Prague, the second choice destination. The reasons often relate to experiences from previous visits (e.g. "Visited Rome in March and enjoyed it a lot - plan to go back in the not too distant future"), and desires to visit somewhere they had never been but would like to see (e.g. "Prague is supposed to be a wonderful city and has been recommended to me to visit").

A small group (7\%) stated that they would be less likely to fly due to the August 2006 security alert and subsequent change in security measures implemented at UK airports. The security measures include restricting each passenger to one item of cabin baggage through the airport security search point and not permitting any liquid within cabin baggage (except essential prescription medicines, baby milk and liquid baby food). Of those stating they would be less likely to fly, the reasons tend to relate to personal risk and the extra 'hassle' incurred; three respondents mention the need for hand luggage either due to small children or for health reasons. It should be noted that the timing of the questionnaire, undertaken in October 2006, means that the August security alert was fresh in respondent's minds. The survey findings do show that the air travel of a small group of passengers would be reduced if there are future security alerts and/or extra delays to check-in and security procedures.

\section{Attitudinal statements}

The Charnwood air travel survey questionnaire includes attitudinal statements relating to both the economic benefits and the environmental disbenefits of increased air travel. A five-point Likert scale was presented to respondents (Strongly agree, Agree, Neither agree or disagree, Disagree and Strongly disagree). Summary results for the sample are shown in Table 3. 
The majority of the sample (76\%) agree with the statement, "Air travel is essential to the UK economy and to the country's continuing prosperity”, taken from the Air Transport White Paper (UK Department for Transport, 2003). Most (66\%) agree that "air travel is a significant contributor to climate change" although there are mixed views on whether the media tends to over-state the climate change effects. There is agreement, therefore, in the economic benefits associated with air travel, but also in terms of the environmental disbenefits associated with climate change. The remaining statements provide a mixed response. In terms of solutions to the negative environmental aspects of aviation, around a quarter of respondents (27\%) agree that passengers should pay more to fly.

\section{Price sensitivity to changes in air fares}

Respondents were asked how their air travel choices might change in the future in response to changes in the costs associated with air travel. They stated whether they would "probably fly more often", have "no change in air travel" and "probably fly less often" for various changes in return air-fares. The proposed price level reductions are by $£ 20$ and $£ 10$ for all return flights; the proposed price rises are by $£ 10, £ 20, £ 50$ and $£ 100$ for all return flights. The prices relate to air fares, low cost or otherwise, including taxes.

In addition, this analysis is not relevant for those that do not currently fly. Therefore, analysis was undertaken for the 282 respondents who had flown the previous year and gave valid responses for each air fare. A price rise of $£ 50$ for all return flights is the price rise that ensures most respondents would "probably fly less often" (65\%).

A group of 'air dependent' respondents (24\%) would not change their air travel even if air fares rose by $£ 100$ for all return flights. This is akin to those acknowledged as car dependent in the literature, extremely reluctant to change behaviour away from their motor car in response to large fuel price increases (Ryley, 2005). There is also evidence of suppressed demand for air travel amongst some respondents. Of the respondents, $39 \%$ would "probably fly more often” at a reduction in return air fares by $£ 20$.

\section{Conclusions}

The Charnwood air travel survey has revealed some interesting insights into air travel preferences of the general public. Individuals are willing to travel long distances to access airports, as evidenced by the proportion in the survey that have used the London airports. Air travel population segments have been identified from the price sensitivity analysis: an 'air dependent' population segment that would not fly less even for a large fare increases, and a group that would fly more often in response to a reduction in fares. Amongst the sample there is majority agreement with the economic benefits (air travel essential to the UK economy) and environmental disbenefits (air travel contributing to climate change) of air travel. 


\section{Acknowledgements}

The air travel survey was funded primarily by a grant from the Faculty of Engineering, Loughborough University. Support also comes from the Engineering and Physical Sciences Research Council, via funding from the 'Propensity to fly' project. Various individuals at East Midlands airport provided input to the questionnaire design, primarily in their Planning Department; particular thanks go to George Hohlacov, Jessica van Ristell, John Froggatt and Brian Conway.

\section{References}

Civil Aviation Authority, 2005. UK Regional Air Services, Civil Aviation Authority Report CAP 754, London.

Cooper, J., Ryley, T. and Smyth, A., 2001. Contemporary lifestyles and the implications for sustainable development policy. Lessons from the UK's most car dependent city, Belfast. Cities, 18, 103-113.

Graham, A, 2006. Have the major forces driving leisure airline traffic changed?, Journal of Air Transport Management, 12,14-20.

Mason, K., J., 2005. Observations of fundamental changes in the demand for aviation services, Journal of Air Transport Management, 11, 19-25.

Ryley, T., 2005. A study of individual travel behaviour in Edinburgh, to assess the propensity to use non-motorised modes. Ph.D. thesis, Napier University.

UK Department for Transport, 2002. The future development of air transport in the United Kingdom: Midlands. UK Department for Transport, London.

UK Department for Transport, 2003. The Future of Air Transport. Air Transport White Paper. HMSO, London. 
Table 1. Routes from East Midlands airport operated by the three low cost airlines in August 2006

\begin{tabular}{|c|c|}
\hline Low cost airline & Route \\
\hline bmi baby & $\begin{array}{l}13 \text { routes: Belfast International, Glasgow, } \\
\text { Edinburgh, Jersey, Prague, Amsterdam, Brussels, } \\
\text { Paris Charles De Gaulle, Geneva, Palma, Alicante, } \\
\text { Malaga \& Faro }\end{array}$ \\
\hline easyJet & $\begin{array}{l}9 \text { routes: Alicante, Cologne/Bonn, Faro, Geneva, } \\
\text { Ibiza, Malaga, Prague, Rome \& Venice }\end{array}$ \\
\hline Ryanair & $\begin{array}{l}17 \text { routes: Derry, Dublin, Shannon, Dinard, Nantes, } \\
\text { Limoges, Bergerac, Nimes, Grenoble, Carcassonne, } \\
\text { Salzburg, Rome, Girona (Barcelona), Murcia } \\
\text { (Spain), Berlin, Lodz \& Warclaw }\end{array}$ \\
\hline
\end{tabular}

Table 2. Sections and variables within the Charnwood air travel survey questionnaire

\begin{tabular}{|c|c|}
\hline Questionnaire section & Variable \\
\hline Air travel experience & $\begin{array}{l}\text { Number of flights the previous year (leisure/business), } \\
\text { details of the most recent return flight, airline } \\
\text { satisfaction, usage of various UK airports }\end{array}$ \\
\hline $\begin{array}{l}\text { Air travel experience from East Midlands } \\
\text { airport (EMA) }\end{array}$ & $\begin{array}{l}\text { Number of EMA flights the previous year, travel mode } \\
\text { to/from EMA, } 8 \text { specified destinations travelled to/from } \\
\text { EMA (Edinburgh, Dublin, Prague, Rome, Berlin, } \\
\text { Alicante, Malaga and Faro) }\end{array}$ \\
\hline Future air travel choices & $\begin{array}{l}\text { Experience \& ranking of } 8 \text { specified destinations, } \\
\text { reasons for } 1^{\text {st }} \text { choice destination, flight choice stated } \\
\text { preference experiment to } 1^{\text {st }} \text { choice destination, } \\
\text { likelihood of travel for this trip, number of people (if } \\
\text { any) respondent would travel with, air travel changes in } \\
\text { response to varying price, air travel changes in response } \\
\text { to August } 2006 \text { security alert }\end{array}$ \\
\hline Attitudes to air travel & $\begin{array}{l}\text { Agreement of respondents with five statements on } \\
\text { economic and environmental issues associated with air } \\
\text { travel }\end{array}$ \\
\hline Household variables & $\begin{array}{l}\text { Age band, gender, length of time at current address, } \\
\text { number of adults in household, number of children in } \\
\text { household, current status (e.g. employed, retired), car } \\
\text { availability, internet access }\end{array}$ \\
\hline
\end{tabular}


Table 3. Responses to attitude statements from the Charnwood air travel survey

\begin{tabular}{lllll}
\hline Statement & $\begin{array}{l}\text { Strongly } \\
\text { agree } \\
\text { or agree }\end{array}$ & $\begin{array}{l}\text { Neither agree } \\
\text { nor disagree }\end{array}$ & $\begin{array}{l}\text { Disagree or } \\
\text { strongly disagree }\end{array}$ & Total \\
\hline $\begin{array}{l}\text { Air travel is essential to the UK } \\
\text { economy and to the country's } \\
\text { continuing prosperity }\end{array}$ & 269 & 72 & 15 & 356 \\
$\begin{array}{l}\text { East Midlands airport should be } \\
\text { expanded to offer more air travel } \\
\text { opportunities }\end{array}$ & 162 & 86 & 109 & 357 \\
$\begin{array}{l}\text { Air travel is a significant contributor } \\
\text { to climate change }\end{array}$ & 235 & 103 & 18 & 356 \\
$\begin{array}{l}\text { The UK media tends to over-state the } \\
\text { effects of climate change }\end{array}$ & 93 & 119 & 144 & 356 \\
$\begin{array}{l}\text { Passengers should pay more to fly } \\
\text { because of the negative environmental } \\
\text { aspects of aviation }\end{array}$ & 96 & 104 & 156 & \\
\hline
\end{tabular}

